\title{
The Effect of Carnitine on the Metabolism of Valproic Acid in Epileptic Patients
}

\author{
Kikuo Sakemi, Kiyoshi Hayasaka, Marie Tahara, \\ Yukiaki Sanada* and Goro Takada \\ Department of Pediatrics, Akita University School of \\ Medicine, Akita 010 and *Department of Pediatrics, Akita \\ Byoin National Sanatorium, Honjo 015
}

Sakemi, K., Hayasaka, K., Tahara, M., Sanada, Y. and Takada, G. The Effect of Carnitine on the Metabolim of Valproic Acid in Epileptic Patients. Tohoku J. Exp. Med., 1992, 167 (2), 89-92 — The half-life of valproic acid (VPA) was studied in 8 epileptic and severely mental retarded patients before and after one month of carnitine supplementation. Serum carnitine concentration was significantly decreased and VPA half-life was prolonged especially in adult patients before carnitine supplementation. After the treatment with carnitine, serum carnitine concentration was increased, and prolonged half-lives of VPA were corrected near to the normal range (from $12.2 \pm 4.2 \mathrm{hr}$ to $9.7 \pm 2.2 \mathrm{hr} ; p<0.05$ ). Controled state of epilepsy was unchanged during the short period of observation. valproic acid ; carnitine; epilepsy; pharmacokineties

Valproic acid (VPA) has been widely used as an effective anticonvulsant for generalized as well as partial seizures, including prophylaxis of febrile convulsion (Wallance and Smith 1980). Nausea and vomiting are usually seen as side effects at the initiation of therapy, but transiently (Browne 1980; Committee on drug 1982). Other side effects are drowsiness, ataxia, tremor, thrombocytopenia, and hepatic dysfunction, including Reye-like syndrome (Gerber et al. 1979). Biochemical studies have shown hyperaminoacidemia, especially hyperglycinemia (Kochi et al. 1979 ; Hayasaka et al. 1980 ; Iinuma et al. 1988), hyperammonemia, and hypocarnitinemia (Ohtani et al. 1982) in VPA-treated patients. Prolonged administration to rats caused an increase in enlarged and less functional mitochondria in liver (Hayasaka et al. 1986). Carnitine supplement has been reported to be effective in reducing the VPA associated hyperammonemia (Ohtani et al. 1982). Carnitine supplement may affect on the metaboilsm of VPA and we studied VPA half-life in patients before and after carnitine supplementation.

\section{Subjects And Methods}

We studied 8 epileptic and severely mental retarded patients who were institutionalized in Akita Byoin National Sanatorium for the handicapped. They were treated with VPA and other anticonvulsants as described in Table 1. No patient had dysfunction of liver and

Received May 27, 1992 ; revision accepted for publication July 16, 1992. 
Table 1. Patient data

\begin{tabular}{|c|c|c|c|c|c|}
\hline \multirow{2}{*}{$\begin{array}{l}\text { Patient } \\
\text { No. }\end{array}$} & \multirow{2}{*}{$\begin{array}{c}\text { Age } \\
\text { (years) }\end{array}$} & \multirow{2}{*}{ Sex } & \multicolumn{2}{|c|}{ VPA therapy } & \multirow{2}{*}{$\begin{array}{c}\text { Other } \\
\text { anticonvulsants }\end{array}$} \\
\hline & & & $\begin{array}{c}\text { Dose } \\
(\mathrm{mg} / \mathrm{kg} / \text { day })\end{array}$ & $\begin{array}{l}\text { Duration } \\
\text { (years) }\end{array}$ & \\
\hline 1 & 7 & $\mathrm{M}$ & 63 & 5.0 & $\mathrm{~PB}^{\mathrm{a}}, \mathrm{PHT}, \mathrm{DZP}$ \\
\hline 2 & 8 & M & 38 & 1.6 & $\mathrm{~PB}, \mathrm{CZP}$ \\
\hline 3 & 13 & $\mathrm{M}$ & 26 & 8.8 & CBZ \\
\hline 4 & 17 & M & 50 & 7.0 & PB, PHT, ACE \\
\hline 5 & 19 & $\mathrm{~F}$ & 31 & 6.3 & $\mathrm{~PB}, \mathrm{ACE}$ \\
\hline 6 & 21 & $\mathrm{~F}$ & 27 & 3.0 & PB, PHT, CBZ, CZP \\
\hline 7 & 22 & $\mathrm{~F}$ & 40 & 7.2 & PHT, CZP, ACE \\
\hline 8 & 37 & M & 27 & 6.8 & $\mathrm{~PB}, \mathrm{CZP}$ \\
\hline
\end{tabular}

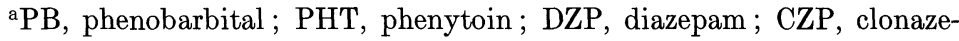
pam, CBZ, carbamazepin; ACE, acetazolamide.

kidney. Mean dose of VPA was $37.8 \mathrm{mg} / \mathrm{kg} /$ day ranged from 26 to $63 \mathrm{mg} / \mathrm{kg} /$ day and mean duration of VPA therapy was 5.7 years ranged from 1.6 to 8.8 years. All anticonvulsants were maintained at their previous doses during the study. Total and free carnitine concentration in serum and VPA half-life were measured before and one month after supplement of DL-carnitine $(40 \mathrm{mg} / \mathrm{kg} /$ day $)$. Serum carnitine was assayed according to the method of Cederblad and Lindstedt (1972) and VPA was by fluorescence polarization immunoassay (TDX, Abbott). The log post-peak serum concentration-time curve after the last dose of VPA was fitted accurately to straight lines (Schobben et al. 1975) and pharmacokinetic parameters were calculated from the data using standard methods. The equation used was $t_{1 / 2}=0.693 / \mathrm{Ke}$, where $t_{1 / 2}$ is the serum half-life of VPA and Ke is elimination rate constant. VPA and other anticonvulsants were administered at $7: 00$ and $19: 00$ and total VPA concentration in serum was measured three times between $13: 00$ and $18: 00$.

\section{RESULTS}

As shown in Table 2, the mean concentration of total and free carnitine in serum was significantly decreased in patients before carnitine supplement and simultaneously prolongation of VPA half-life was observed especially in adult patients. After carnitine supplement for one month, concentration of total and free carnitine in serum was significantly elevated and prolonged half-lives of VPA were shortened near to the normal range (from $12.2 \pm 4.2 \mathrm{hr}$ to $9.7 \pm 2.2 \mathrm{hr} ; p<$ 0.05). Frequency of seizures in each patient was unchanged during two months of observation. 
TABLE 2. VPA half-life and serum carnitine concentration before and after carnitine supplementation ${ }^{\mathrm{a}}$

\begin{tabular}{|c|c|c|c|c|c|c|c|c|}
\hline \multirow[b]{2}{*}{ Patient } & \multicolumn{2}{|c|}{$\begin{array}{l}\text { Total carnitine } \\
(\mathrm{nmol} / \mathrm{ml})\end{array}$} & \multicolumn{2}{|c|}{$\begin{array}{l}\text { Free carnitine } \\
(\mathrm{nmol} / \mathrm{ml})\end{array}$} & \multicolumn{2}{|c|}{$\begin{array}{l}\text { VPA half-life } \\
(\mathrm{hr})\end{array}$} & \multicolumn{2}{|c|}{$\begin{array}{l}\text { Frequency of } \\
\text { seizure }^{\mathrm{b}} \\
\text { (times } / \text { month) }^{\text {ant }}\end{array}$} \\
\hline & Before & After & Before & After & Before & After & Before & After \\
\hline 1 & 10.9 & 73.6 & 5.2 & 55.8 & 6.8 & 6.3 & 27 & 26 \\
\hline 2 & 20.4 & 56.0 & 16.4 & 37.9 & 9.1 & 8.0 & 15 & 13 \\
\hline 3 & 24.5 & 74.9 & 15.5 & 47.4 & 9.2 & 9.5 & 2 & 2 \\
\hline 4 & 23.7 & 57.1 & 13.9 & 43.8 & 16.2 & 12.1 & 16 & 12 \\
\hline 5 & 43.9 & 55.0 & 34.1 & 46.5 & 18.1 & 12.6 & 0 & 0 \\
\hline 6 & 55.0 & 60.3 & 34.0 & 52.7 & 8.6 & 8.3 & 10 & 13 \\
\hline 7 & 19.4 & 48.6 & 14.9 & 35.2 & 15.0 & 9.2 & 0 & 0 \\
\hline 8 & 21.7 & 56.6 & 15.0 & 43.3 & 14.8 & 11.3 & 5 & 4 \\
\hline \multicolumn{9}{|c|}{ Mean \pm S.D. $27.4 \pm 14.660 .3 \pm 9.2^{* *} 18.6 \pm 10.1 \quad 45.3 \pm 6.9^{* *} 12.2 \pm 4.29 .7 \pm 2.2^{*}$} \\
\hline $\begin{array}{l}\text { Normalc }^{c} \\
\text { range }\end{array}$ & \multicolumn{2}{|c|}{$49.0 \pm 13.4$} & \multicolumn{2}{|c|}{$44.2 \pm 12.2$} & \multicolumn{2}{|c|}{$\begin{array}{l}9.5 \pm 2.1 \text { (adults) } \\
9.2 \pm 3.5 \text { (children) }\end{array}$} & & \\
\hline
\end{tabular}

aDL-Carnitine was supplemented for one month at a dosage of $40 \mathrm{mg} / \mathrm{kg} / \mathrm{day}$.

${ }^{b}$ Clinical effect was estimated at two months after carnitine supplement.

'Normal ranges of carnitine and half-life from Ohtani et al. (1982) and Redenbaugh et al. (1980).

${ }^{*} p<0.05,{ }^{* *} p<0.01$, vs. before carnitine supplementation.

\section{Discussion}

Administration of VPA decreased the concentration of total and free carnitine in serum as previously reported (Ohtani et al. 1982). Simultaneously, prolongation of VPA half-life was observed especially in adult patients and was corrected near to the normal range by carnitine supplement. VPA is metabolized mainly by glucuronidation and partly by several oxidative pathways including $\beta$-oxidation (Gugler and von Unruh 1980). Physiologically, carnitine has a significant role in the oxidation of long chain fatty acids, allowing long chain acyl-CoA esters to cross the mitochondrial membrane. A further role of carnitine may be to protect cells against toxic accumulation of acyl-CoA compounds of either endogenous or exogenous origin by trapping such acyl groups as carnitine esters, which may be excreted in urine. There was no change in urinary excretion of major oxidative metabolites of VPA under carnitine supplement (data not shown). Therefore, the effect of carnitine on VPA metabolism appears unrelated to $\beta$-oxidation of short chain fatty acid, VPA, but it might be related to promoting the excretion of toxic acyl-CoA compounds in urine and to improving the metabolism of VPA. VPA half-life is slightly shorter in children than that in adults (Redenbaugh et al. 1980). The glucuronidation of VPA in children may be more active than that in adults, resulting in less accumulation of acl-CoA 
compounds in children. Frequency of seizures in each patient was unchanged during two months of observation. Further cases should be studied for long term.

\section{Acknowledgments}

We thank Dr. Hitoshi Tada for advice on pharmacological analysis of VPA.

\section{References}

1) Browne, T.R. (1980) Valproic acid. N. Engl. J. Med., 302, 661-666.

2) Cederblad, G. \& Lindstedt, S. (1972) A method for the determination of carnitine in the picomol range. Clin. Chim. Acta, 37, 235-243.

3) Committee on drug (1982) Valproic acid: Benefits and risks. Pediatrics, 70, 316319.

4) Gerber, N., Dickinson, R.G., Harland, R.C., Lynn, R.K., Houghton, D., Antonias, J.I. \& Schimschck, J.C. (1979) Reye-like syndrome associated with valproic acid therapy. J. Pediatr., 95, 142-144.

5) Gugler, R. \& von Unruh, G.E. (1980) Clinical pharmacokinetics of valproic acid. Clin. Pharmacokinet., 5, 67-83.

6) Hayasaka, K., Kochi, H., Hiraga, K. \& Kikuchi, G. (1980) Occurrence of a catalytically less active glycine decarboxylase in the liver of rat treated with dipropylacetic acid. Biochem. Int., 1, 410-416.

7) Hayasaka, K., Takahashi, I., Kobayashi, Y., Iinuma, K., Narisawa, K. \& Tada, K. (1986) Effects of valproate on biogenesis and function of liver mitochondria. Neurology, 36, 351-356.

8) Iinuma, K., Hayasaka, K., Narisawa, K., Tada, K. \& Hori, K. (1988) Hyperaminoacidaemia and hyperammonaemia in epileptic children treated with valproic acid. Eur. J. Pediatr., 148, 267-269.

9) Kochi, H., Hayasaka, K., Hiraga, K. \& Kikuchi, G. (1979) Reduction of the level of the glycine cleavage system in the rat liver resulting from administration of dipropylacetic acid: An experimental approach to hyperglycinemia. Arch. Biochem. Biophys., 198, 589-597.

10) Ohtani, Y., Endo, F. \& Matsuda, I. (1982) Carnitine deficiency and hyperammonemia associated with valproic acid therapy. J. Pediatr., 101, 782-785.

11) Redenbaugh, J.E., Sato, S., Penry, J.K., Dreifuss, F.E. \& Kupferberg, H.J. (1980) Sodium valproate: Pharmacokinetics and effectiveness in treating intractable seizures. Neurology, 30, 1-6.

12) Schobben, F., van der Kleijn, E. \& Gabreëls, F.J.M. (1975) Pharmacokinetics of Di-N-Propylacetate in epileptic patients. Eur. J. clin. Pharmacol., 8, 97-105.

13) Wallance, S.J. \& Smith, J.A. (1980) Successful prophylaxis against febrile convulsions with valproic acid or phenobarbitone. Br. Med. J., 280, 353-354. 